\title{
The Capital Structure Decisions of New Firms
}

Second in a series of reports using data from the Kauffman Firm Survey

November 2008
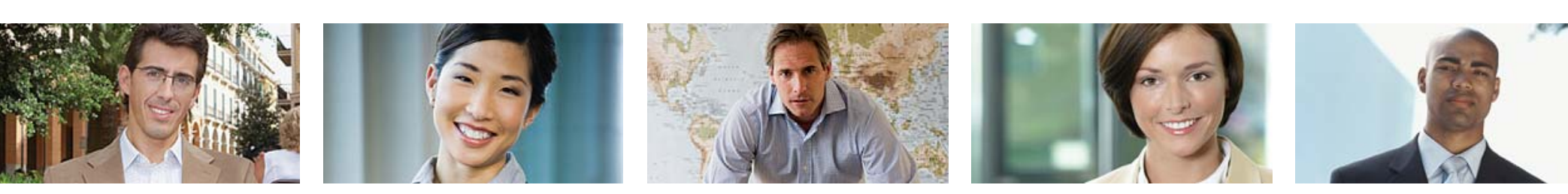

KAUFFMAN

The Foundation of Entrepreneurship

Kauffman Firm Survey

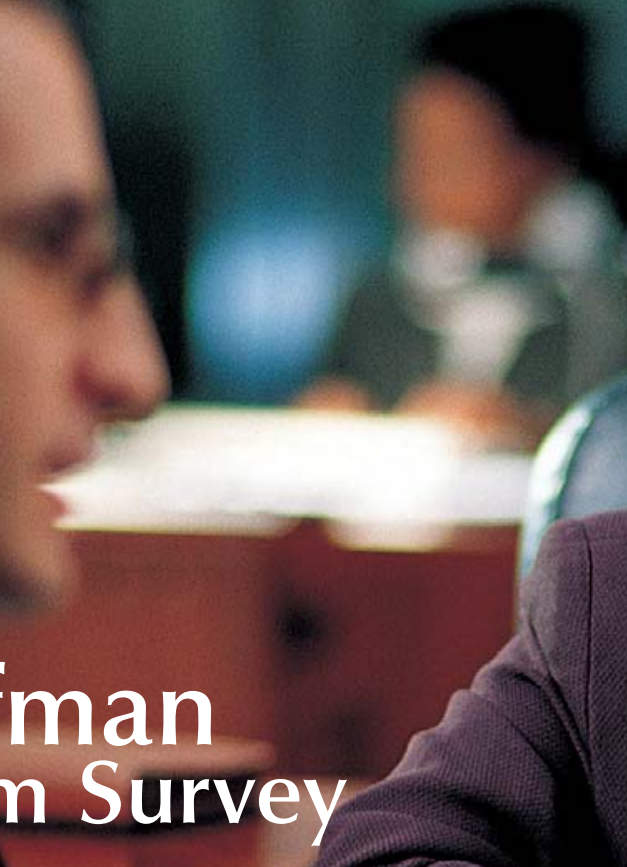

西

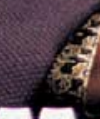

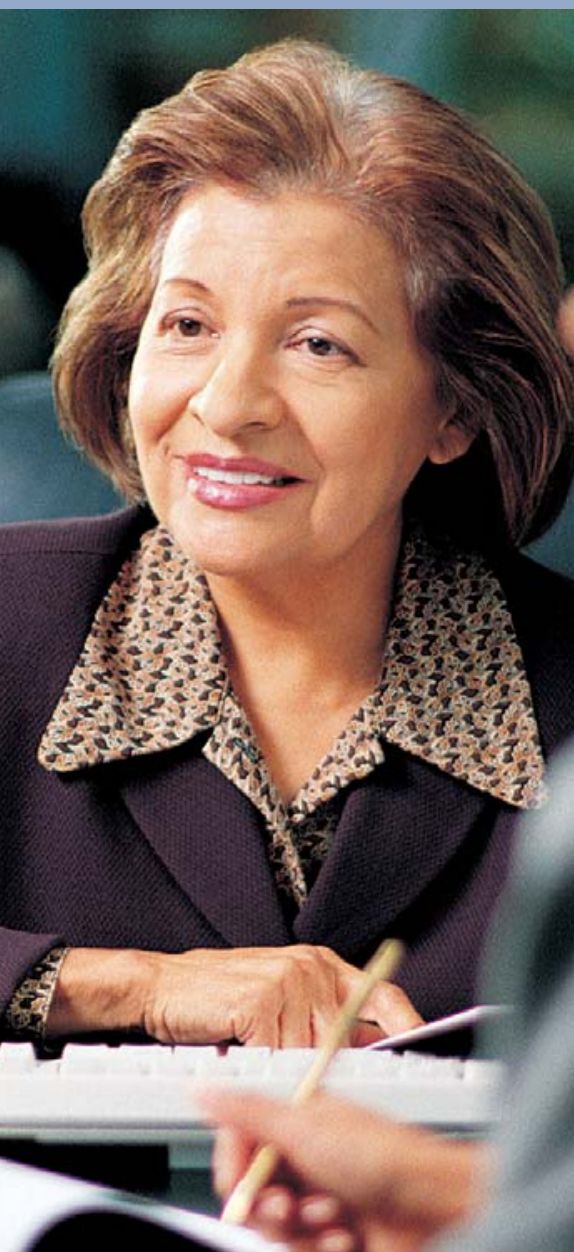

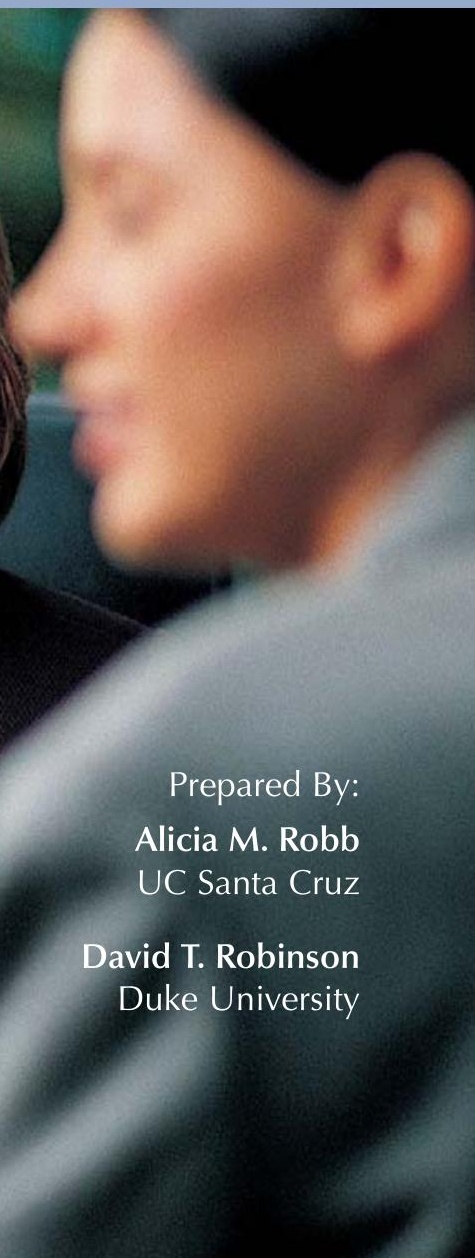




\section{Kauffman Firm Survey}

\section{The Capital Structure Decisions of New Firms}

Second in a series of reports using data from the Kauffman Firm Survey

November 2008

\section{KAUFFMAN}

The Foundation of Entrepreneurship

The authors are grateful to the Kauffman Foundation for generous financial support and to the participants at the Kauffman/Cleveland Federal Reserve Bank Entrepreneurial Finance Pre-Conference for helpful comments on an earlier draft. The usual disclaimer applies. 


\section{ABSTRACT}

This paper investigates the capital structure choices that firms make in their initial year of operations, using restricted-access data from the Kauffman Firm Survey. Contrary to many accounts of startup activity, the firms in our data rely heavily on external debt sources, such as bank financing, and less heavily on friends and family-based funding sources. This striking fact holds even when we purge each firm's credit score of variation due to demand-side credit characteristics. The heavy reliance on external debt underscores the importance of wellfunctioning credit markets for the success of nascent business activity.

\section{TABLE OF CONTENTS}

Section I: Introduction

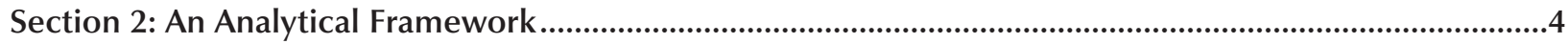

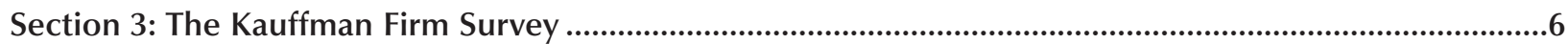

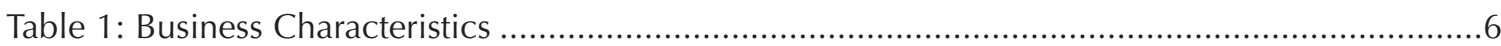

Table 2: Cash Flow Characteristics of Startups in the KFS .............................................................

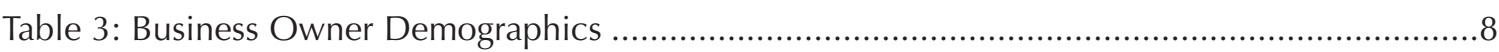

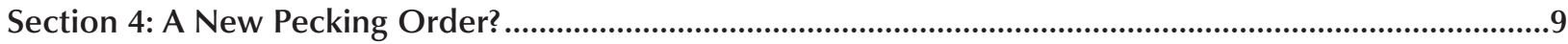

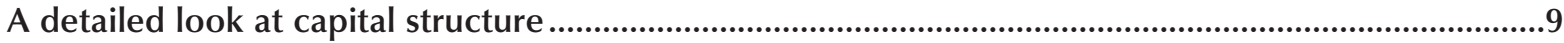

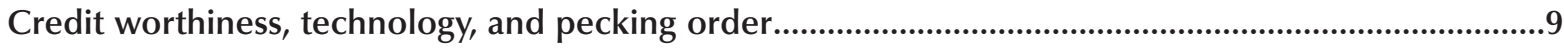

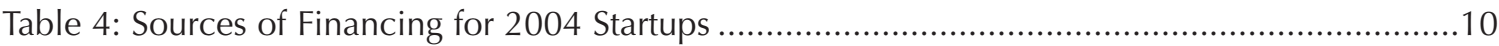

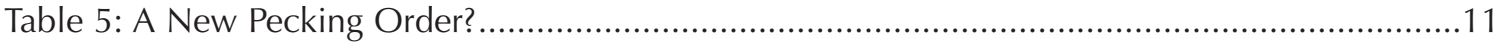

Separating credit supply from credit demand ...........................................................................................11

Table 6: Sources of Financing for 2004 Startups (Model 1 and Model 4) ....................................13

Table 7: Pecking Order Differences Between High-Access and Low-Access Firms ........................14

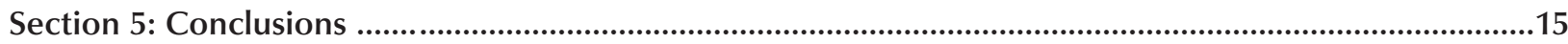

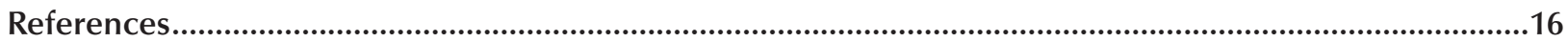


U

nderstanding how capital markets affect the growth and survival of nascent firms is perhaps the central question of entrepreneurial finance. Yet, most of what we know about entrepreneurial finance comes from firms that already have received venture capital funding or are on the verge of going public. The dearth of data on very early stage firms makes it difficult for researchers to look further back in firms' life histories. Even data sets that are oriented towards small business do not allow us to systematically measure the decisions that firms make at their founding. This paper uses a novel data set, the Kauffman Firm Survey (KFS), to study the behavior and decision-making that firms make at their very earliest stages of life. As such, it provides a first-time glimpse into the capital structure decisions of truly nascent firms.

In this paper we use the confidential, restrictedaccess version of the KFS, which tracks nearly 5,000 firms from their birth in 2004 through the first three years of life. 'Because the survey identifies firms at the very earliest stages of life and follows the cohort over time, recording growth, death, and any later funding events, it provides a rich picture of firms' early capital structure decisions.

To motivate and guide our analysis of the KFS data, we begin by developing a simple analytical framework that allows us to highlight two sets of issues that nascent firms face. In particular, we develop a simple model of capital structure choice in a world of asymmetric information. In this world, firms can choose what types of securities to issue when they raise capital. They also can choose from whom to raise capital. This second choice captures the fact that potential funding sources differ in the amount of asymmetric information they have regarding the firm's quality. Holding constant the identity of the funding source, the classic pecking order of Myers and Majluf is obtained, in which firms first use internal resources, then debt, then equity. But by allowing the identity to vary, the pecking order is overturned easily.

While simple, this analytical framework is tailored to the situation facing small firms, which often choose between funding sources that are "nearby" or "informal" —friends, family, personal contactsor more distant or formal funding sources, such as banks, angel investors, or venture capital firms. Using this simple framework, we explore the capital structure choices that firms make.

Our findings underscore the importance of external capital sources for new firms. It is widely believed that many startup firms rely on a motley array of informal investors-sometimes referred to as friends, family and fools - to finance the early stages of life. One of our key results is that nascent firms rely heavily on external debt financing, such as that provided by local banks and credit cards.

Indeed, our calculations indicate that external debt financing-primarily through owner-backed bank loans and business credit cards-is the primary source of financing at a firm's inception. The average amount of bank financing is seven times greater than the average amount of insider-financed debt; three times as many firms rely on outside debt as do inside debt. Even if we discard firms that do not use this source of financing, the average amount of external debt is nearly twice that of internal debt.

Of course, these calculations only speak to the equilibrium amount of borrowing from inside and outside sources; they are driven by both the supply of credit, as well as the demand for credit. To control for the fact that there simply may be much more readily available outside funding, we make use of Dun \& Bradstreet credit scores of the firms. By regressing the credit score on industry dummies, as well as firm and owner characteristics that affect the demand for capital (such as the business's legal form of organization and the owner's education), we can purge the credit score of demand-side variation,

1 To be eligible for inclusion in the KFS, at least one of the following activities had to have been performed in 2004 and none performed in a prior year: Payment of state unemployment (UI) taxes; Payment of Federal Insurance Contributions Act (FICA) taxes; Presence of a legal status for the business; Use of an Employer Identification Number (EIN); Use of Schedule C to report business income on a personal tax return. 
leaving us with a measure of supply-side variation in credit access. Using this strategy to partition the data into firms with easy access versus constrained access to capital, we can explore how much the capital structure decisions of nascent firms are driven by supply-side factors.

Surprisingly, this partitioning has little effect on the observed capital structure choices firms make. To be sure, firms with high unexplained credit scores have more financial capital- they are nearly three times larger on average than constrained-access firms. But the relative amount of outside debt to total capital is about the same as those firms with limited access to capital.

Studying the capital structure of nascent firms helps to shed light on existing models of capital structure by focusing on an environment in which many of the modeling assumptions are particularly salient. At a theoretical level, many theories of capital structure are built from asymmetric information models of the firm that explicitly model the firm as an owner-managed entity seeking to raise funding to begin a project of uncertain value to outside investors. Most large, modern corporations simply do not fit this description. Yet the types of firms covered by the Kauffman Firm Survey fit this description well. As such, they provide a natural laboratory for testing the predictions of many existing theories of capital structure. At the same time, small firms typically do not have access to public equity and debt markets in the ways that typically are envisioned by traditional capital structure theories. Thus, while the links between the underlying motives for capital structure choicesignaling motives based on asymmetric information, and incentive motives based on moral hazard-are presumably acute among these firms, the standard capital structure choices that are observed among large firms are simply not present here.

This paper is related to a number of papers in finance literature that test capital structure theories from a variety of perspectives. Perhaps most directly related is a series of papers beginning with ShyamSunder and Myers (1999), which develops a test of the Pecking Order theory of Myers and Majluf (1984). While Shyam-Sunder and Myers (1999) finds evidence in favor of the pecking order, a number of papers following this were critical of their approach. Chirinko and Singha (2000) argue that the tests proposed by Shyam-Sunder and Myers (1999) do not really discriminate between Pecking Order and Tradeoff theory of Myers (1977). Frank and Goyal (2001) argue that the Shyam-Sunder and Myers (1999) results are driven by the fact that small, young firms on Compustat are excluded from their study, and methodological issues notwithstanding, the results do not extend to small firms. In that regard, our work picks up where Frank and Goyal (2000) leave off, because we focus on the very smallest, youngest firms, years or even decades before they are large enough to become listed on Compustat.

Our work also touches on a growing literature that links social networks to financial market outcomes. Robinson and Stuart (2007) show that strategic alliances between better networked firms involve greater pledged cash and are less likely to involve equity stakes. Similarly, Bengtsson and Sensoy (2008) show that the level of experience of a venture capital firm affects the contractual structure it employs. These results indicate that reputational links formed in the network of communications between firms substitute for many of the contractual mechanisms that underpin financial contracts.

The remainder of the paper is as follows. We begin in Section 2 by laying out a simple framework for analyzing capital structure decisions of firms. Then, in Section 3, we describe the KFS data in greater detail. Section 4 examines initial capital structure choices. Section 5 concludes. 


\section{AN ANALYTICAL FRAMEWORK}

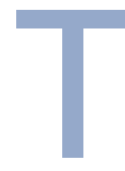

his section motivates the empirical analysis by providing a simple analytical framework for studying capital structure decisions of new firms. The standard pecking order of Myers and Majluf (1984) predicts that firms will first use internal cash, then use debt, and then use outside equity. A number of problems arise when applying this to small firms. First, the theory envisions that firms have access to public capital markets. Second, if the model is taken literally, it concerns a tradeoff between diluting claims on existing assets and funding new projects. Is this concern really salient for small firms?

At a broader level, most empirical support (for example, Shyam-Sunder and Myers 1999) relies on excluding small firms from the data. Frank \& Goyal (2002) show that including young firms destroys empirical validity of pecking order. Likewise, Garmaise (2007) develops alternative pecking order where better knowledge of outsider flips the predictions of Myers and Majluf. Recent work by Cole (2007) and others argues broad support for pecking order predictions in small firms.

Thus, our goal here is to produce a simple model in which asymmetric information between insiders and outsiders generates a pecking order that not only establishes equilibrium choices between debt and equity, but also between insiders and outsiders. To do this, we begin by assuming a simple twoperiod framework with no discounting. An entrepreneur owns a project but needs to raise $\mathrm{F}>0$ at time 1 to undertake a project. The project generates time-2 payoff $X \in\left\{X_{L}, X_{H}\right\}$.

Critically, there is asymmetric information surrounding firm quality. In particular, firms can be either Good-type firms or Bad-type firms. $\operatorname{Pr}\left(X=X_{H}\right)$ $=\theta \in\left\{\theta_{\mathrm{B}}, \theta_{\mathrm{G}}\right\}$ reflects the fact that high-type firms have a higher probability of reaching the high outcome at time 2 than Bad-type firms. We assume that potential investors hold priors on $\mathrm{G}$ given by $\eta$, so that the average success probability is $\ddot{O}=\eta \theta_{\mathrm{G}}+(1-\eta) \theta_{\mathrm{B}}$.

For simplicity, we assume that all projects are positive Net Present Value; some are just better than others. This assumption means that a pooling equilibrium is feasible, and in some sense, desirable: positive NPV projects are all being funded; it is just that some firms face capital costs that are too high.

A security in this environment is a state-contingent claim $\left\{R_{L}, R_{H}\right\}$ that allocates cash flows to investors. By limited liability, $R_{\llcorner}<X_{\llcorner}$and $R_{H}<X_{H}$.

By solving for the security that lowers the cost of being confused with Bad types, we can demonstrate the classic pecking order. The value of the high-type firm in a perfect world:

$V_{G}=X_{L}+\theta_{G}\left(X_{H}-X_{L}\right)-F$

However, to raise $F$ in an imperfect capital market we paid: $\wedge F=R_{L}+O \ddot{O}\left(R_{H}-R_{L}\right)$ instead of $F=R_{L}+\theta_{G}\left(R_{H}-R_{L}\right)$. Thus: $V_{G}=X_{L}+\theta_{G}\left(X_{H}-X_{L}\right)-\wedge F$

Substituting this in, we can write this as the sum of the firm's actual value plus the discount associated with information asymmetry as follows: $X_{\llcorner}+\theta_{G}\left(X_{H}-X_{\llcorner}\right)-F-\left(\theta_{G}-O\right)\left(R_{H}-R_{\llcorner}\right)$

(------Firm Value------)(--Info Asymmetry--)

- The costs of the information asymmetry are given by $\theta_{G}-$ Ö.

- These costs are minimized by picking securities that make $R_{H}$ - R $\mathrm{R}_{\mathrm{L}}$ small.

The typical approach in the context of public firms is to think about this problem formally as minimizing $R_{H}-R_{\llcorner}$subject to investor's participation, two limited liability constraints, and critically, an exogenous information structure.

If debt, will look like debt with face value:

$K=R_{H}=X_{\llcorner}+\left\{F-X_{L}\right\} /$ Ö.

If equity, will look like fraction $\alpha$ satisfying $\alpha=F /\left\{X_{L}+\ddot{O}\left(X_{H}-X_{L}\right)\right\}$.

The cost of the information asymmetry is lower for debt than equity whenever the following condition holds: $O ̈>\left\{F-X_{B}\right\}\left\{X_{H}-X_{L}\right\}$

This always is satisfied by the assumption that all projects are positive NPV. In general, it will be satisfied as long as the average project is "good enough." 
Equation 4 gives the classic result: When managers know more than the market, managers wish to avoid issuing risky securities. Thus, a pecking order arises:

1. First use internal cash,

2. Then issue debt,

3. Then issue equity.

But this is all assuming that the amount of information asymmetry is constant. What if this is not fixed?

Info. Asymmetry $=\left(\theta_{\mathrm{G}}-\theta_{\mathrm{i}}\right)\left(\mathrm{R}_{H}-\mathrm{R}_{\mathrm{L}}\right)$ (from whom)(what type)

This final expression captures the core of the model, which is that firms have a choice not only surrounding the type of capital structure they choose, but also regarding from whom they seek financing. This key insight guides our empirical analysis. 


\section{SECTION 3}

\section{THE KAUFFMAN FIRM SURVEY}

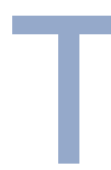

he KFS is a longitudinal survey of new businesses in the United States. This survey collected information on 4,928 firms that started in 2004 and surveys them annually. These data contain detailed information on both the firm and up to ten business owners per firm. In addition to the 2004 baseline year data, there are two years of follow-up data (2005 and 2006) now available. Additional years are planned. Detailed information on the firm includes industry, physical location, employment, profits, intellectual property, and financial capital (equity and debt) used at startup and over time.

Information on up to ten owners includes age, gender, race, ethnicity, education, previous industry experience, and previous startup experience. For more information about the KFS survey design and methodology, please see Ballou et. al (2008). A public-use data set is available for download from the Kauffman Foundation's Web site and a more detailed confidential data set is available to researchers through a secure, remote access data enclave provided by the National Opinion Research Center (NORC). For more details about how to access these data, please see www.kauffman.org/kfs.

A subset of the confidential data set is used in this research - those firms that have data for all three survey years and those that have been verified as going out of business in either 2005 or 2006. This reduces the sample size to 4,163 businesses. The method we used for assigning owner demographics at the firm level was to define a primary owner. For firms with multiple owners (35 percent of the sample), the primary owner was designated by the largest equity share. In cases where two or more owners owned equal shares, hours worked and a series of other variables were used to create a rank ordering of owners to define a primary owner. (For more information on this methodology, see Ballou et. al (2008). For this research, multirace/ethnic owners are classified into one race/ethnicity category based on the following hierarchy: black, Asian,
Table 1 Business Characteristics

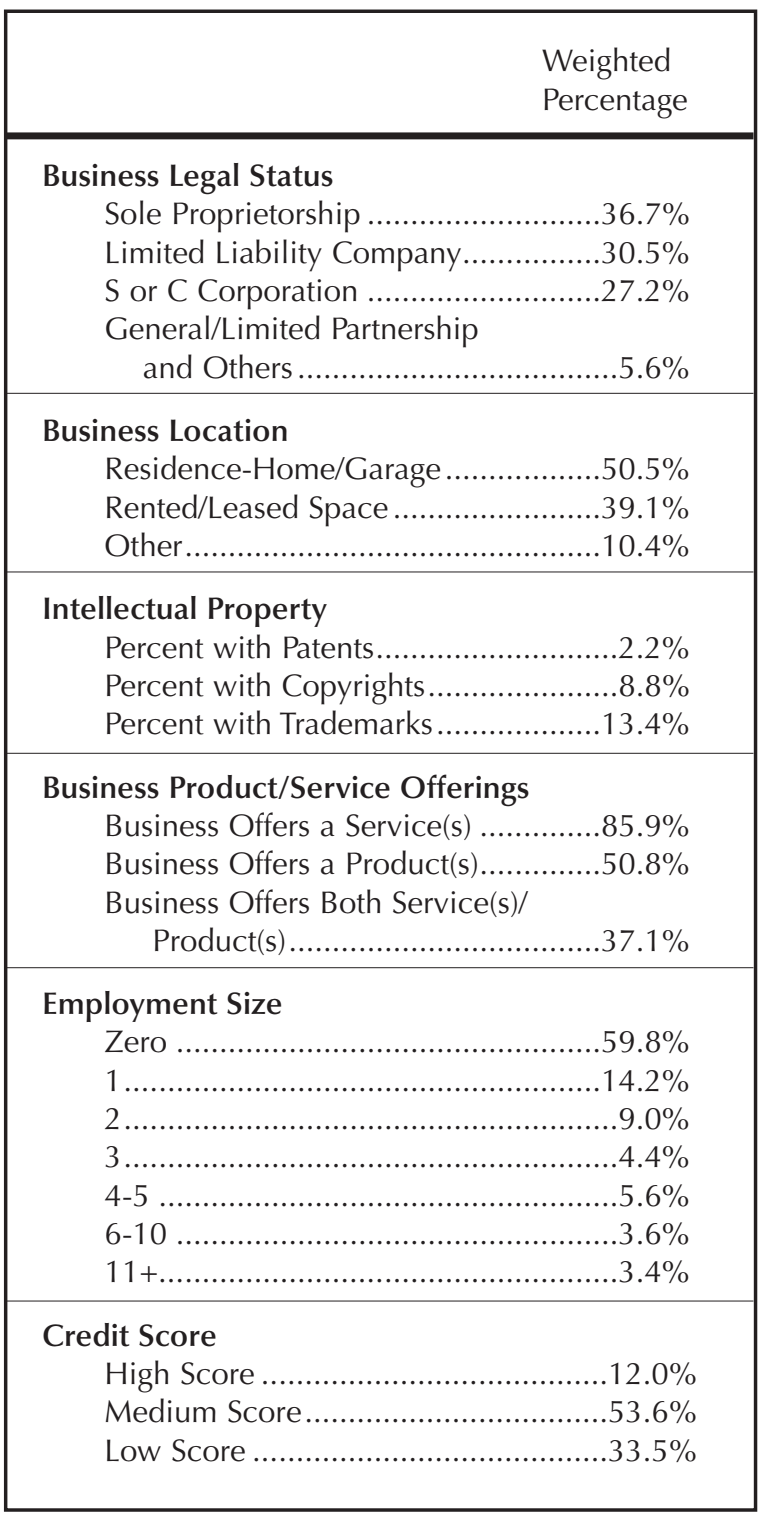

Source: Kauffman Firm Survey Microdata. Sample Size: 4,163.

other, Hispanic, and white. For example, an owner is defined as black, even if he/she is also Hispanic. As a result of the ordering, the white category includes only non-Hispanic white. 
Table 2: Cash Flow Characteristics of Startups in the KFS

\begin{tabular}{|c|c|}
\hline \multicolumn{2}{|c|}{ Panel A: Percent of Businesses by Revenues and Expenses } \\
\hline $\begin{array}{l}\text { Weighted } \\
\text { Percentage }\end{array}$ & $\begin{array}{l}\text { Weighted } \\
\text { Percentage }\end{array}$ \\
\hline Revenues & Expenses \\
\hline$\ldots \ldots \ldots \ldots \ldots \ldots \ldots \ldots \ldots \ldots \ldots \ldots \ldots \ldots \ldots \ldots . .5 \%$ & $\ldots \ldots \ldots .7 .0 \%$ \\
\hline$\ldots \ldots \ldots \ldots \ldots \ldots \ldots \ldots \ldots \ldots \ldots \ldots \ldots \ldots \ldots \ldots \ldots . .1 \%$ & $\$ 1,000$ or less ............. \\
\hline . & $\$ 1,001-\$ 5,000 \ldots \ldots \ldots . .$. \\
\hline 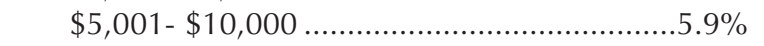 & 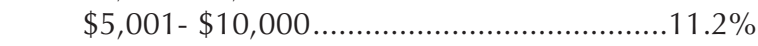 \\
\hline 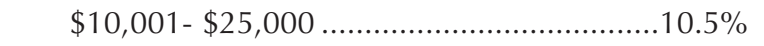 & 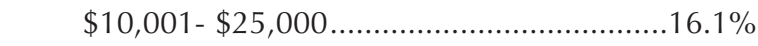 \\
\hline 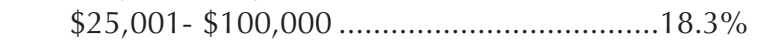 & 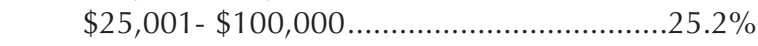 \\
\hline 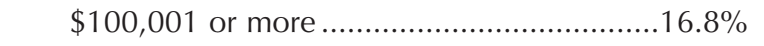 & $\$ 100,001$ or more....................................15.8\% \\
\hline \multicolumn{2}{|c|}{ Panel B: Percent of Businesses by Amount of Profits or Losses } \\
\hline $\begin{array}{r}\text { Weighted } \\
\text { Percentage } \\
\end{array}$ & $\begin{array}{r}\text { Weighted } \\
\text { Percentage }\end{array}$ \\
\hline Profit & Loss \\
\hline 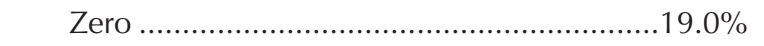 & Zero............................................................. \\
\hline$\$ 1,000$ or less …...................................... $9.8 \%$ & $\$ 1,000$ or less ....................................... 14.0\% \\
\hline 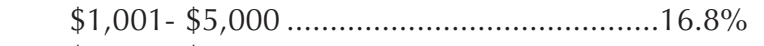 & 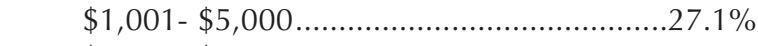 \\
\hline 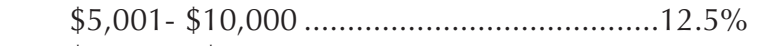 & 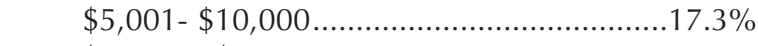 \\
\hline$\$ 10,001-\$ 25,000 \ldots \ldots \ldots \ldots \ldots \ldots \ldots \ldots \ldots \ldots \ldots \ldots \ldots \ldots \ldots \ldots \ldots \ldots \ldots \ldots . .17 .4 \%$ & $\$ 10,001-\$ 25,000 \ldots \ldots \ldots \ldots \ldots \ldots \ldots \ldots \ldots \ldots \ldots \ldots \ldots \ldots \ldots \ldots \ldots \ldots \ldots \ldots . . .17 .2 \%$ \\
\hline 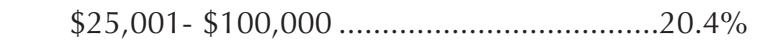 & 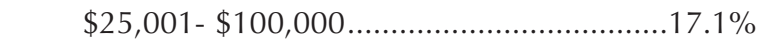 \\
\hline 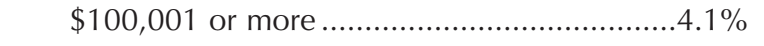 & $\$ 100,001$ or more \\
\hline
\end{tabular}

Source: Kauffman Firm Survey Microdata. Sample Size 4,163.

Tables 1 and 2 provide details on business characteristics. In Table 1, we report key features of the business-its legal form, location, and other features of operations. Thirty five percent of all businesses in the data are sole proprietorships, while the remaining 65 percent are structured to provide some form of limited liability to owners. However, less than 30 percent of businesses are incorporated, and of these, only 8 percent of the sample is incorporated as a C-corporation.

More than half of the businesses in the survey operate out of the respondent's home or garage; the vast majority (86 percent) market a service, and only a quarter of the firms in the survey have any form of intellectual property. Reflecting the fact that they are being measured at their inception, the firms also are tiny by almost any conceivable measure. Nearly 60 percent of the firms have no employees other than the founder, and less than 8 percent of firms in the sample have more than five employees in their first year of operation.

Table 2 considers the cash flow characteristics of these nascent businesses. Even though these firms are small, nearly 20 percent of firms (17 percent) have more than $\$ 100,000$ in revenue in their first year. Indeed, 45 percent of the firms in the sample have more than $\$ 10,000$ in annual revenue in their first year. Of course, more than 57 percent of firms 
Table 3

Business Owner Demographics

\begin{tabular}{|c|c|}
\hline $\begin{array}{l}\text { Weighted } \\
\text { Percentage }\end{array}$ & $\begin{array}{l}\text { Weighted } \\
\text { Percentage }\end{array}$ \\
\hline Gender & Years of Industry Experience \\
\hline 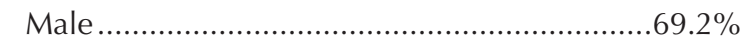 & 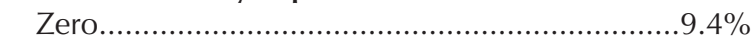 \\
\hline Female & 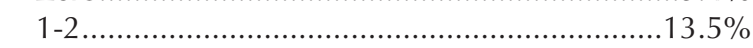 \\
\hline & $\ldots \ldots \ldots \ldots \ldots \ldots . . .16 .0 \%$ \\
\hline Race & $\ldots . . . \ldots . . . .9 \%$ \\
\hline White & ......................13.8\% \\
\hline 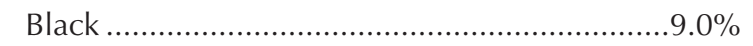 & 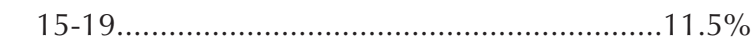 \\
\hline 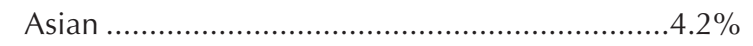 & 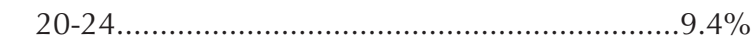 \\
\hline 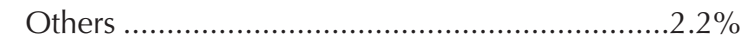 & 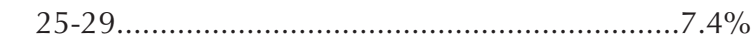 \\
\hline & $\ldots . . .9 .2 \%$ \\
\hline \multicolumn{2}{|l|}{ Ethnicity } \\
\hline Non-Hispanic ...............................................94.2\% & Previous Business Startups \\
\hline \multirow[t]{2}{*}{ 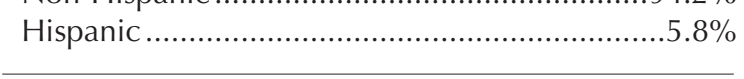 } & 0 \\
\hline & 1 \\
\hline \multirow{7}{*}{ 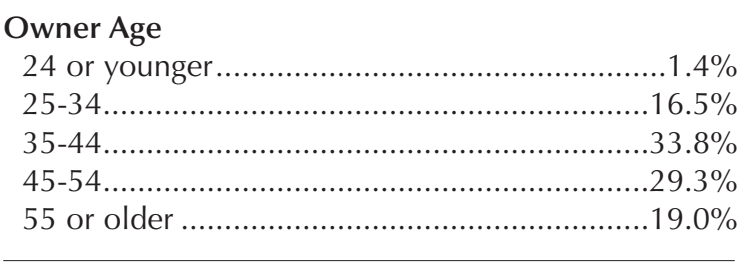 } & 2 \\
\hline & 3 \\
\hline & 4 or more \\
\hline & 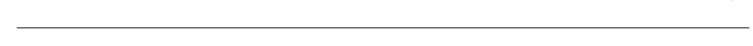 \\
\hline & Hours Worked \\
\hline & 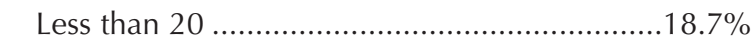 \\
\hline & 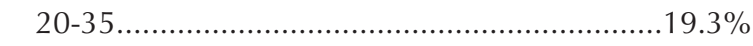 \\
\hline \multirow{9}{*}{ 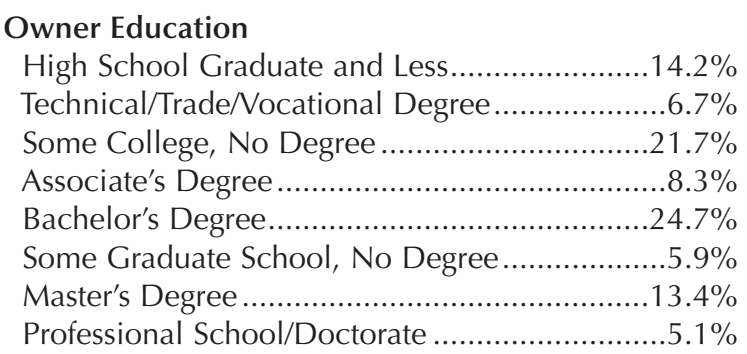 } & 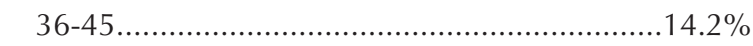 \\
\hline & 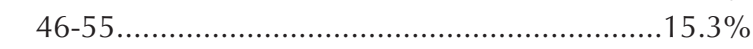 \\
\hline & 56 or more \\
\hline & \\
\hline & \\
\hline & \\
\hline & \\
\hline & \\
\hline & \\
\hline
\end{tabular}

Source: Kauffman Firm Microdata. Sample Size 4,163.

have more than $\$ 10,000$ in expenses, and almost one firm in four reports zero profit or loss.

Table 3 examines owner characteristics in more detail. The entrepreneurs in our data are overwhelmingly male and white: less than 31 percent of firms have a primary owner that is female and nearly 79 percent are non-Hispanic white. In spite of the fact that most of the businesses in our data begin at home, in people's garages, with fewer than five employees, the overwhelming majority of business owners have at least some industry experience. Less than 10 percent of owners have no industry experience, while more than half have more than five years of experience. Likewise, more than 40 percent of business owners have started a business before. 


\section{A NEW PECKING ORDER?}

T he standard prescription from pecking order models is that firms first should use internal cash, then rely on debt financing, then rely on equity financing. Of course, the standard pecking order model does not account for the possibility that firms can choose from whom to raise capital, as well as what type of capital to raise. How well does the pecking order describe how nascent firms actually make financing decisions?

\section{A detailed look at capital structure}

In Table 4, we provide a detailed look at the capital structure choices that nascent firms make. It provides a breakdown of thirty different sources of capital for startup businesses. Over 75 percent of firms have at least some owner equity; of these, the mean amount is just over $\$ 34,500$. If we include those firms with no equity, the average equity amount drops to $\$ 27,365$.

Owner debt plays a much smaller role. Only about one-quarter of firms have some form of owner personal debt, and the vast majority of this is mostly in the form of debt carried on an owner's personal credit card. The overall average amount of credit card debt used to finance startups is a modest $\$ 3,200$, but this includes the roughly 75 percent of owners who do not use personal credit cards to start their businesses. Among those who do, the balance is considerably larger- $\$ 10,000$, or about one-third of the size of the owner equity.

While the owner-level capital structure is heavily tilted towards equity, the capital structure of insiders and outsiders is completely reversed. If we include the firms with zero values, the ratio of debt to equity is about five to one for both insiders and outsiders. But most outside capital is raised as debt; seven times as many firms report outside debt as report outside equity. Yet, among those who do receive outside equity, the average amount is twice as large as the overall average for all firms.

Insider equity is relatively uncommon. Only about 5 percent of the sample relies on equity from a spouse or other family members, and the overall average amount is only about 2 percent of the average funding. Yet, among the group who uses family equity, the source is important: The magnitude of insider equity is roughly the same as that of owner equity and many times larger than the magnitude of owner debt, for those few firms that rely on it.

Insider debt is more common, but still a small source of funding relative to outside debt and equity. The mean value of inside debt for all firms is $\$ 7,605$, and this primarily comes from personal loans received by the respondent from family and other owners. Loans directly to the business from owners or other family members also are important, but the fact that less than 10 percent of surveyed firms rely on any one type of inside debt suggests that this funding source is not relied upon by most firms.

Several striking patterns emerge from Table 4. First, outside capital is extremely important, even at the youngest stages of a firm's life. The average firm has approximately $\$ 78,000$ of financial capital. Of that, roughly half comes from outside sources. Second, the vast majority of this outside capital comes in the form of credit, either through personal loans made directly to the owner or through business credit cards. Outside equity is rare, and is used for large injections of capital.

In some respects, these findings suggest that pecking order does a good job of describing the capital structure decisions of nascent firms. If we treat owner debt and equity as internal funding, and abstract away from its capital structure, then we see that many firms rely on internal funding, fewer firms rely on debt, and fewer still rely on equity. This broadly conforms to the basic message of the Myers and Majluf pecking order. At the same time, this characterization misses important details, because it abstracts away from the interaction between capital choice (debt vs. equity) and from whom to raise capital.

\section{Credit worthiness, technology, and pecking order}

Table 5 takes the richness of Table 4 and boils it down to six categories: owner debt, owner equity, inside debt, inside equity, outside debt, and outside 
Table 4

Sources of Financing for 2004 Startups

\begin{tabular}{|c|c|c|c|}
\hline All & All Firms Mean & All $>0$ Mean & $\mathrm{N}$ \\
\hline Owner Equity & $\$ 27,365$ & $\$ 34,509$ & 3292 \\
\hline $\begin{array}{l}\text { Insider Equity } \\
\text { Spouse } \\
\text { Parents }\end{array}$ & $\begin{array}{r}\$ 1,695 \\
\$ 479 \\
\$ 1,217\end{array}$ & $\begin{array}{l}\$ 34,984 \\
\$ 28,697 \\
\$ 34,509\end{array}$ & $\begin{array}{r}186 \\
67 \\
3292\end{array}$ \\
\hline $\begin{array}{l}\text { Outsider Equity } \\
\text { Other informal investors } \\
\text { Businesses } \\
\text { Government } \\
\text { Venture Capitalists } \\
\text { Others }\end{array}$ & $\begin{array}{r}\$ 6,979 \\
\$ 2,736 \\
\$ 1,807 \\
\$ 401 \\
\$ 1,655 \\
\$ 380\end{array}$ & $\begin{array}{r}\$ 150,733 \\
\$ 101,718 \\
\$ 162,097 \\
\$ 81,821 \\
\$ 335,868 \\
\$ 183,295\end{array}$ & $\begin{array}{r}223 \\
121 \\
61 \\
26 \\
28 \\
10\end{array}$ \\
\hline $\begin{array}{l}\text { Owner Debt } \\
\text { Personal CC balances, respondent } \\
\text { Personal CC balances, other owners } \\
\text { Personal owner loan }\end{array}$ & $\begin{array}{r}\$ 3,506 \\
\$ 3,179 \\
\$ 304 \\
\$ 23\end{array}$ & $\begin{array}{l}\$ 11,695 \\
\$ 10,899 \\
\$ 10,008 \\
\$ 15,853\end{array}$ & $\begin{array}{r}1221 \\
1185 \\
133 \\
5\end{array}$ \\
\hline $\begin{array}{l}\text { Insider Debt } \\
\text { Personal family loan, respondent } \\
\text { Personal family loan, other owners } \\
\text { Business loan from family } \\
\text { Business loan from owner } \\
\text { Business loan from employees } \\
\text { Other personal loan, respondent } \\
\text { Other personal debt, respondent }\end{array}$ & $\begin{array}{r}\$ 7,605 \\
\$ 2,798 \\
\$ 276 \\
\$ 1,258 \\
\$ 1,732 \\
\$ 66 \\
\$ 592 \\
\$ 883\end{array}$ & $\begin{array}{r}\$ 51,221 \\
\$ 28,656 \\
\$ 34,689 \\
\$ 42,610 \\
\$ 118,065 \\
\$ 19,349 \\
\$ 30,046 \\
\$ 69,567\end{array}$ & $\begin{array}{r}564 \\
350 \\
28 \\
116 \\
64 \\
9 \\
78 \\
51\end{array}$ \\
\hline $\begin{array}{l}\text { Outsider Debt } \\
\text { Personal bank loan, respondent } \\
\text { Business CC balance, respondent } \\
\text { Personal bank loan, other owners } \\
\text { Business CC balance, other owners } \\
\text { Business CC balances, business } \\
\text { Business bank loan } \\
\text { Credit line } \\
\text { Non-bank business loan } \\
\text { Government business loan } \\
\text { Other business loan } \\
\text { Other individual loan } \\
\text { Other business debt }\end{array}$ & $\begin{array}{r}\$ 31,255 \\
\$ 11,066 \\
\$ 1,358 \\
\$ 1,430 \\
\$ 190 \\
\$ 856 \\
\$ 9,357 \\
\$ 3,237 \\
\$ 2,033 \\
\$ 721 \\
\$ 163 \\
\$ 246 \\
\$ 597\end{array}$ & $\begin{array}{r}\$ 85,681 \\
\$ 65,154 \\
\$ 9,710 \\
\$ 62,251 \\
\$ 11,929 \\
\$ 7,417 \\
\$ 150,704 \\
\$ 62,156 \\
\$ 123,622 \\
\$ 80,333 \\
\$ 61,586 \\
\$ 52,529 \\
\$ 122,512\end{array}$ & $\begin{array}{r}1487 \\
669 \\
556 \\
97 \\
62 \\
463 \\
242 \\
216 \\
75 \\
37 \\
20 \\
21 \\
21\end{array}$ \\
\hline $\begin{array}{l}\text { Total } \\
\mathrm{N}\end{array}$ & $\begin{array}{r}\$ 78,406 \\
4,163\end{array}$ & see column & \\
\hline
\end{tabular}

Source: Kauffman Firm Survey Microdata. Sample Size 4,163. 
equity. These classifications are as described in the left-most column of Table 4. Reducing the amount of detail not only makes the pecking order that most firms use more apparent, it also facilitates a ready comparison across different types of firms.

The rows of Table 5 are arranged from highest to lowest in terms of the overall weighted average level of 2004 funding. If we interpret the magnitudes as an indication of relative importance, then we see a clear pecking order emerge: first outside debt, then owner equity, then debt from insiders. Fourth in the pecking order is outside equity, followed by owner debt; the least used source is inside equity.

An alternative way to characterize the pecking order of nascent firms is to combine owner debt and equity into a single category, internal funding. Look at capital structure this way, the average nascent firm is roughly equal parts internal funding and outside debt. These two sources of funding are each roughly four times larger than the next largest source of financing. Regardless of how the financial pieces are assembled, outside debt plays a paramount role in funding nascent firms.

One reason for this simply may be that outside debt is more plentiful than other sources of funding. To explore this possibility, we used firm credit scores to identify high-credit worthiness and low-credit worthiness firms. Table 5 shows that while high- credit worthiness firms have access to much more financial capital, they access capital in roughly the same proportions as low-credit worthiness firms. Thus, a firm's credit score induces a first-order shift in the level of financing it obtains, but only a second-order shift in the capital structure choice it makes.

Outside equity plays a substantially more important role in the capital structure of high-tech firms. Across all high-tech firms, outside equity is the third-largest funding source behind outside debt and owner equity. Among high-tech firms with highcredit scores, outside equity is the largest form of financing. It is only the low-credit score firms in the high-tech sector that display a pecking order that resembles the average nascent firm in our data.

\section{Separating credit supply from demand}

To separate credit supply and credit demand, we exploit the availability of credit score information to identify cases in which firms faced unexpectedly easy or difficult access to capital. If the capital structure choices depicted in Table 5 are polluted by differences in the availability of capital, then this should control for that.

To account for this possibility, we regress the Dun \& Bradstreet credit score on variables that proxy for demand-side factors that would influence credit

Table 5

A New Pecking Order?

\begin{tabular}{|l|r|r|r|r|r|r|}
\cline { 2 - 7 } \multicolumn{1}{c|}{} & \multicolumn{3}{c|}{ ALL FIRMS } & \multicolumn{3}{c|}{ HIGH-TECH FIRMS ONLY } \\
\cline { 2 - 8 } & All & $\begin{array}{c}\text { High-Credit } \\
\text { Score }\end{array}$ & $\begin{array}{c}\text { Low-Credit } \\
\text { Score }\end{array}$ & All & $\begin{array}{c}\text { High-Credit } \\
\text { Score }\end{array}$ & $\begin{array}{c}\text { Low-Credit } \\
\text { Score }\end{array}$ \\
\hline Outsider Debt & $\$ 31,255$ & $\$ 57,940$ & $\$ 19,472$ & $\$ 41,690$ & $\$ 80,216$ & $\$ 21,626$ \\
\hline Owner Equity & $\$ 27,365$ & $\$ 42,950$ & $\$ 18,307$ & $\$ 46,754$ & $\$ 57,297$ & $\$ 37,183$ \\
\hline Insider Debt & $\$ 7,605$ & $\$ 15,844$ & $\$ 4,812$ & $\$ 10,612$ & $\$ 20,857$ & $\$ 12,541$ \\
\hline Outsider Equity & $\$ 6,979$ & $\$ 13,689$ & $\$ 3,212$ & $\$ 31,136$ & $\$ 108,457$ & $\$ 11,646$ \\
\hline Owner Debt & $\$ 3,506$ & $\$ 3,354$ & $\$ 3,245$ & $\$ 4,435$ & $\$ 3,241$ & $\$ 6,384$ \\
\hline Insider Equity & $\$ 1,695$ & $\$ 2,504$ & $\$ 1,195$ & $\$ 2,191$ & $\$ 3,510$ & $\$ 2,660$ \\
\hline Total & $\$ 78,406$ & $\$ 136,281$ & $\$ 50,242$ & $\$ 136,818$ & $\$ 273,578$ & $\$ 92,040$ \\
\hline $\mathbf{N}$ & 4163 & $\mathbf{5 0 2}$ & $\mathbf{1 3 2 2}$ & $\mathbf{5 9 2}$ & $\mathbf{8 9}$ & $\mathbf{1 3 3}$ \\
\hline
\end{tabular}

Source: Kauffman Firm Survey Microdata. Sample Size 4,163. 
ratings. We consider two models. First, we run the following regression: score $_{i j}=\alpha+\beta_{j}+\varepsilon_{\mathrm{i}}$ where score sij is the credit score of firm $i$ in industry $\mathrm{j} ; \beta_{\mathrm{j}}$ are industry fixed effects. Thus, the first estimation simply includes a set of 60 industry dummies.

For the second specification, we run the following regression: score $_{i j}=\alpha+\beta_{j}+\gamma F_{i j}+\varepsilon_{i}$ where score is the credit score of firm i in industry $j$, $\beta_{\text {s }}$ are industry fixed effects, and $F$ is a vector of firmand owner-level characteristics that likely vary with demand for credit.

For this specification, we include a full set of industry dummies, a set of education dummies corresponding to the breakdown presented in Table 3, and we also include factors, such as race, ethnicity, work experience, intellectual property, legal structure of the enterprise, as well as whether it is home-based. While these coefficient estimates are interesting in their own right, a full discussion is beyond the scope of this paper. Indeed, in Robb, Fairlie, and Robinson (2008) we explore the issue of race and access to credit in greater detail.

The idea behind both specifications is that by purging the credit score of variation that is linked to factors driving the demand for credit, the remaining variation in credit score would reflect supply-side credit restrictions. Firms with high, unexplained credit scores should have easier access to capital, while firms with low, unexplained credit scores should have relatively difficult access to capital. Moreover, the differences in their access to capital should reflect suppliers' willingness to lend, rather than differences in capital needs. Recovering the regression errors from these two models gives us a mechanism for classifying firms as credit constrained or unconstrained. Of course, a firm with a low unconditional credit score is constrained, but this low score may arise endogenously because the firm has little need for external capital, low growth prospects, and, therefore, does not take the steps needed to boost its credit score. By relying on the conditional credit score as opposed to the raw credit score, we circumvent these problems.

Tables 6 and 7 report pecking orders for firms in the lowest and highest quintiles of the unexplained credit score distribution. Firms in the lowest quintile face the most severe unexplained restrictions to credit access, since their credit scores are much lower than would be predicted based on their demand characteristics. In contrast, the top quintile has the easiest access to credit, since these firms have high, unexplained credit scores, given their access to capital. Table 6 presents the detailed classification of funding sources, while Table 7 presents the aggregated data.

In general, the results of Tables 6 and 7 mimic the results from the previous table, in that they show a first-order effect on the amount of capital raised, but only a second-order effect on capital structure choice. Credit constrained firms have capital structures that look very similar to those of unconstrained firms. The primary difference is that unconstrained firms have much higher levels of capital investment. 
Table 6

Sources of Financing for 2004 Startups

\begin{tabular}{|c|c|c|c|c|}
\hline \multirow[b]{2}{*}{ All } & \multicolumn{2}{|c|}{$\begin{array}{c}\text { Model } 1 \\
\text { Residual Quintiles }\end{array}$} & \multicolumn{2}{|c|}{$\begin{array}{c}\text { Model } 4 \\
\text { Residual Quintiles }\end{array}$} \\
\hline & Top & Bottom & Top & Bottom \\
\hline Owner Equity & $\$ 39,481$ & $\$ 18,672$ & $\$ 34,123$ & $\$ 24,915$ \\
\hline $\begin{array}{l}\text { Insider Equity } \\
\text { Spouse } \\
\text { Parents }\end{array}$ & $\begin{array}{r}\$ 3,017 \\
\$ 564 \\
\$ 2,452\end{array}$ & $\begin{array}{r}\$ 1,497 \\
\$ 546 \\
\$ 951\end{array}$ & $\begin{array}{r}\$ 2,257 \\
\$ 180 \\
\$ 2,077\end{array}$ & $\begin{array}{r}\$ 1,879 \\
\$ 807 \\
\$ 1,072\end{array}$ \\
\hline $\begin{array}{l}\text { Outsider Equity } \\
\text { Other informal investors } \\
\text { Businesses } \\
\text { Government } \\
\text { Venture Capitalists } \\
\text { Others }\end{array}$ & $\begin{array}{r}\$ 14,216 \\
\$ 3,961 \\
\$ 2,789 \\
\$ 1,006 \\
\$ 6,344 \\
\$ 116\end{array}$ & $\begin{array}{r}\$ 4,117 \\
\$ 1,176 \\
\$ 288 \\
\$ 151 \\
\$ 1,081 \\
\$ 1,420\end{array}$ & $\begin{array}{r}\$ 8,550 \\
\$ 3,242 \\
\$ 508 \\
\$ 707 \\
\$ 3,981 \\
\$ 112\end{array}$ & $\begin{array}{r}\$ 6,813 \\
\$ 1,973 \\
\$ 1,709 \\
\$ 333 \\
\$ 1,336 \\
\$ 1,462\end{array}$ \\
\hline $\begin{array}{l}\text { Owner Debt } \\
\text { Personal CC balances, respondent } \\
\text { Personal CC balances, other owners } \\
\text { Personal owner loan }\end{array}$ & $\begin{array}{r}\$ 3,651 \\
\$ 3,383 \\
\$ 268 \\
\$-\end{array}$ & $\begin{array}{r}\$ 3,351 \\
\$ 2,793 \\
\$ 553 \\
\$ 4\end{array}$ & $\begin{array}{r}\$ 3,334 \\
\$ 3,104 \\
\$ 230 \\
\$-\end{array}$ & $\begin{array}{r}\$ 3,965 \\
\$ 3,301 \\
\$ 659 \\
\$ 4\end{array}$ \\
\hline $\begin{array}{l}\text { Insider Debt } \\
\text { Personal family loan, respondent } \\
\text { Personal family loan, other owners } \\
\text { Business loan from family } \\
\text { Business loan from owner } \\
\text { Business loan from employees } \\
\text { Other personal loan, respondent } \\
\text { Other personal debt, respondent } \\
\text { Other personal loan, other owners }\end{array}$ & $\begin{array}{r}\$ 13,033 \\
\$ 3,448 \\
\$ 143 \\
\$ 4,000 \\
\$ 3,752 \\
\$ 302 \\
\$ 858 \\
\$ 530 \\
\$-\end{array}$ & $\begin{array}{r}\$ 6,574 \\
\$ 3,610 \\
\$ 76 \\
\$ 1,166 \\
\$ 501 \\
\$ 14 \\
\$ 449 \\
\$ 758 \\
\$-\end{array}$ & $\begin{array}{r}\$ 12,307 \\
\$ 3,178 \\
\$ 499 \\
\$ 3,984 \\
\$ 3,131 \\
\$ 151 \\
\$ 835 \\
\$ 529 \\
\$-\end{array}$ & $\begin{array}{r}\$ 7,437 \\
\$ 3,613 \\
\$ 163 \\
\$ 1,437 \\
\$ 556 \\
\$ 13 \\
\$ 636 \\
\$ 1,018 \\
\$-\end{array}$ \\
\hline $\begin{array}{l}\text { Outsider Debt } \\
\text { Personal bank loan, respondent } \\
\text { Business CC balance, respondent } \\
\text { Personal bank loan, other owners } \\
\text { Business CC balance, other owners } \\
\text { Business CC balances, business } \\
\text { Business bank loan } \\
\text { Credit line } \\
\text { Non-bank business loan } \\
\text { Government business loan } \\
\text { Other business loan } \\
\text { Other individual loan } \\
\text { Other business debt }\end{array}$ & $\begin{array}{r}\$ 51,629 \\
\$ 15,106 \\
\$ 1,330 \\
\$ 2,051 \\
\$ 453 \\
\$ 1,200 \\
\$ 14,001 \\
\$ 10,150 \\
\$ 3,026 \\
\$ 1,408 \\
\$ 372 \\
\$ 535 \\
\$ 1,998\end{array}$ & $\begin{array}{r}\$ 18,758 \\
\$ 6,837 \\
\$ 735 \\
\$ 1,759 \\
\$ 267 \\
\$ 783 \\
\$ 5,967 \\
\$ 955 \\
\$ 715 \\
\$ 276 \\
\$ 44 \\
\$ 30 \\
\$ 390\end{array}$ & $\begin{array}{r}\$ 44,115 \\
\$ 12,492 \\
\$ 1,153 \\
\$ 1,071 \\
\$ 87 \\
\$ 1,232 \\
\$ 11,966 \\
\$ 9,779 \\
\$ 2,943 \\
\$ 738 \\
\$ 341 \\
\$ 522 \\
\$ 1,791\end{array}$ & $\begin{array}{r}\$ 28,798 \\
\$ 8,425 \\
\$ 952 \\
\$ 2,423 \\
\$ 324 \\
\$ 969 \\
\$ 11,087 \\
\$ 1,753 \\
\$ 1,364 \\
\$ 895 \\
\$ 45 \\
\$ 40 \\
\$ 522\end{array}$ \\
\hline Total & $\$ 125,027$ & $\$ 52,969$ & $\$ 104,687$ & $\$ 73,807$ \\
\hline $\mathrm{N}$ & 790 & 820 & 810 & 811 \\
\hline
\end{tabular}

Source: Kauffman Firm Survey Microdata. Sample Size 4,163. 
Table 7

Pecking Order Differences Between High-Access and Low-Access Firms

Panel A: Regression Based on INDUSTRY CONTROLS

\begin{tabular}{|l|c|c|c|c|c|c|}
\cline { 2 - 7 } \multicolumn{1}{c|}{} & Bottom Mean & $\begin{array}{c}\text { Quintile } \\
\text { Percentage }\end{array}$ & Top Mean & $\begin{array}{c}\text { Quintile } \\
\text { Percentage }\end{array}$ & $\begin{array}{c}\text { Difference } \\
\text { Mean }\end{array}$ & Percentage \\
\hline Owner Equity & $\$ 18,672$ & $35.3 \%$ & $\$ 39,481$ & $31.6 \%$ & $\$ 20,809$ & $3.7 \%$ \\
\hline Insider Equity & $\$ 1,497$ & $2.8 \%$ & $\$ 3,017$ & $2.4 \%$ & $\$ 1,520$ & $0.4 \%$ \\
\hline Outsider Equity & $\$ 4,117$ & $7.8 \%$ & $\$ 14,216$ & $11.4 \%$ & $\$ 10,099$ & $-3.6 \%$ \\
\hline Owner Debt & $\$ 3,351$ & $6.3 \%$ & $\$ 3,651$ & $2.9 \%$ & $\$ 301$ & $3.4 \%$ \\
\hline Insider Debt & $\$ 6,574$ & $12.4 \%$ & $\$ 13,033$ & $10.4 \%$ & $\$ 6,459$ & $2.0 \%$ \\
\hline Outsider Debt & $\$ 18,758$ & $35.4 \%$ & $\$ 51,629$ & $41.3 \%$ & $\$ 32,871$ & $-5.9 \%$ \\
\hline Total & $\$ 52,969$ & $100.0 \%$ & $\$ 125,027$ & $100.0 \%$ & $\$ 72,059$ & $0.0 \%$ \\
\hline Zero FK in 2004 & & $11.7 \%$ & & $9.2 \%$ & & $2.5 \%$ \\
\hline
\end{tabular}

Panel B: Regression Based on FULL MODEL

\begin{tabular}{|l|c|c|c|c|c|c|}
\cline { 2 - 7 } \multicolumn{1}{c|}{} & Bottom Mean & $\begin{array}{c}\text { Quintile } \\
\text { Percentage }\end{array}$ & Top Mean & $\begin{array}{c}\text { Quintile } \\
\text { Percentage }\end{array}$ & $\begin{array}{c}\text { Difference } \\
\text { Mean }\end{array}$ & Percentage \\
\hline Owner Equity & $\$ 24,915$ & $33.8 \%$ & $\$ 34,123$ & $32.6 \%$ & $\$ 9,208$ & $1.2 \%$ \\
\hline Insider Equity & $\$ 1,879$ & $2.5 \%$ & $\$ 2,257$ & $2.2 \%$ & $\$ 378$ & $0.4 \%$ \\
\hline Outsider Equity & $\$ 6,813$ & $9.2 \%$ & $\$ 8,550$ & $8.2 \%$ & $\$ 1,738$ & $1.1 \%$ \\
\hline Owner Debt & $\$ 3,965$ & $5.4 \%$ & $\$ 3,334$ & $3.2 \%$ & $\$(630)$ & $2.2 \%$ \\
\hline Insider Debt & $\$ 7,437$ & $10.1 \%$ & $\$ 12,307$ & $11.8 \%$ & $\$ 4,870$ & $-1.7 \%$ \\
\hline Outsider Debt & $\$ 28,798$ & $39.0 \%$ & $\$ 44,115$ & $42.1 \%$ & $\$ 15,317$ & $-3.1 \%$ \\
\hline Total & $\$ 73,807$ & $100.0 \%$ & $\$ 104,687$ & $100.0 \%$ & $\$ 30,880$ & $0.0 \%$ \\
\hline
\end{tabular}

Source: Kauffman Firm Survey Microdata. Sample Size 4,163. 


\section{SECTION 5}

\section{CONCLUSION}

his paper uses a novel data set to explore the capital structure decisions that firms make in their first year of operations. In the vast majority of cases, this is when the firms in question still are being incubated in their founders' homes or garages, before outside employees have joined the firm in any numbers, and certainly well before the firms in question would be attractive to the types of funding sources that are the focus of most discussions of early stage financing.

Despite these firms being at the very beginning of life, they rely to a surprising degree on outside capital. The notion that startups rely on the beneficence of a loose coalition of family and friends seems misleading given our findings. Instead, roughly 80 percent to 90 percent of most firms' startup capital is made up in equal parts of owner equity and bank debt. While a large fraction of this bank debt is owed by the founder, rather than the firm, the fact that the debt is financed through arm's length relationships, and not through family and friends networks, is worthy of further research.

To be sure, our findings underscore the importance of liquid credit markets for the formation and success of young firms. If nascent firms hold the key to growth in western economies, then surely economic growth hinges critically on the smooth functioning of credit markets that enable young firms to be formed, to grow, and to succeed. 


\section{REFERENCES}

Chirinko, Robert S. and Anuja R. Singha, 2000. "Testing static tradeoff against pecking order models of capital structure: a critical comment," Journal of Financial Economics, vol. 58, no. 3.

Fairlie, Robert and Harry Krashinsky, 2007. "Liquidity constraints, household wealth, and entrepreneurship revisited," working paper, University of California, Santa Cruz.

Fairlie, Robert and Alicia Robb, 2008. "Why are black-owned businesses less successful than white-owned businesses: The role of families, inheritances, and business human capital," Journal of Labor Economics, 25(2): 289-323.

Frank, Murray and Vidhan Goyal, 2003. "Testing the pecking order theory of capital structure," Journal of Financial Economics, vol. 67, no. 2.

Hurst, Erik and Annamaria Lusardi, 2004. "Liquidity constraints, household wealth, and entrepreneurship," Journal of Political Economy, vol. 112.

Myers, Steward and Nicholas Majluf, 1984. "Financing and investment decisions when firms have information markets do not have," Journal of Financial Economics, vol. 13, no. 2.

Myers, 1984. "The capital structure puzzle," Journal of Finance, vol. 39, no. 3.

Robb, Alicia M., Robert Fairlie, and David T. Robinson, 2008. "Capital injections among new black and white business ventures: Evidence from the Kauffman Firm Survey," working paper.

Shyam-Sunder and Stewart Myers, 1999. "Testing static tradeoff against pecking order models of capital structure," Journal of Financial Economics, vol. 51. 


\section{Kauffman \\ Firm Survey}




\section{KAUFFMAN}

The Foundation of Entrepreneurship

4801 ROCKHILL ROAD

KANSAS CITY, MISSOURI 64110

816-932-1000

www.kauffman.org 